\title{
TTR
}

Traduction, terminologie, re?daction

\section{Translation, Quotation, Iterability}

\section{Steven Rendall}

Volume 10, numéro 2, 2e semestre 1997

L'essai sur la traduction de Walter Benjamin : traductions critiques Walter Benjamin's Essay on Translation: Critical Translations

URI : https://id.erudit.org/iderudit/037303ar

DOI : https://doi.org/10.7202/037303ar

Aller au sommaire du numéro

\section{Éditeur(s)}

Association canadienne de traductologie

ISSN

0835-8443 (imprimé)

1708-2188 (numérique)

Découvrir la revue

Citer cet article

Rendall, S. (1997). Translation, Quotation, Iterability. TTR, 10(2), 167-189.

https://doi.org/10.7202/037303ar

\section{Résumé de l'article}

Traduction, citation, itérabilité - Dans la " traductibilité " on peut voir un cas particulier de la propriété linguistique générale à laquelle Derrida a donné le nom d'« itérabilité ». En me penchant sur l'itérabilité je cherche à mieux définir la place de la traduction dans la pensée de Benjamin et en même temps à suggérer une nouvelle perspective sur la traduction elle-même.

Comme la citation, la traduction n'emploie pas le texte original, mais plutôt le mentionne ou le nomme. Ainsi on peut comprendre la défense benjaminienne de la traduction mot-à-mot (Wörtlichkeit); si comme la citation la traduction dénote le texte de l'original, elle traduit non pas le sens mais le mot de l'original. De même, la traduction connote la traduction elle-même en tant qu'acte possible, ou pour le dire comme Benjamin et Rodolphe Gasché, elle communique la traductibilité. L'itérabilité, la traductibilité, la citabilité constituent cette part de la structure d'une entité linguistique qui diffère de l'entité en soi et se réfère à quelque chose au-delà. Pour Benjamin, cet au-delà, c'est le langage pur.

Tous droits réservés ( C TTR: traduction, terminologie, rédaction — Les auteurs, Ce document est protégé par la loi sur le droit d’auteur. L’utilisation des 1997 services d'Érudit (y compris la reproduction) est assujettie à sa politique d'utilisation que vous pouvez consulter en ligne.

https://apropos.erudit.org/fr/usagers/politique-dutilisation/ 


\title{
Translation, Quotation, Iterability
}

\author{
Steven Rendall
}

Near the beginning of his well-known essay, "The Translator's Task" ("Die Aufgabe des Übersetzers"), Walter Benjamin states flatly : "Translation is a form."' A form or mode of what? one is inclined to ask. Although Benjamin never offers an explicit answer to this question, one can infer from his argument that translation is a mode of the continuing life - the Überleben or Nachleben - of art works. I would further suggest, still following Benjamin's argument though not his terminology, that translation is a mode of the repetition or iteration of language. Since this claim is central to my argument, I shall start by trying to justify it.

In a stimulating paper on Benjamin's theory of language, Rodolphe Gasché reads "The Translator's Task" in connection with Benjamin's early essay "On Language as Such and on the

\footnotetext{
1 "Übersetzung ist eine Form." Gesammelte Schriften, ed. Rolf Tiedemann and Hermann Schweppenhäuser, Werkausgabe (Frankfurt am Main, Suhrkamp, 1980), II, 1:9. Subsequent references to Benjamin's works will cite this edition. Unless otherwise noted, all translations are mine.
} 
Language of $\mathrm{Man}^{\text {"2 }}$ Gasché argues that in the latter work Benjamin is trying to define the absolute ground which is presupposed by any philosophy of language, and which, in order to provide such a foundation, must be of an entirely different order from language itself. Benjamin's metaphysical theory of language posits that every thing participates in language, for "it is essential to every thing to communicate its spiritual content. ${ }^{13}$ This spiritual content is not the thing itself but the part of the thing that is communicable, mitteilbar, and is therefore already linguistic in nature, though it must always be distinguished from the linguistic means by which it is communicated. In Benjamin's account, which is explicitly modeled on the first chapter of Genesis, and perhaps implicitly on Baudelaire's "Correspondances," this spiritual content is the residue of the divine act of creation through the word; mutely communicating their linguistic nature to human beings, things call out for recognition of their divine origin. Now if we ask what language itself communicates, what its spiritual content or essence is, the answer, Gasche suggests, is that language communicates communicability itself. Similarly, Gasché argues, translatability, Ubersetzbarkeit, is what is communicated by translation :

In the same way that communicability indicates a yearning of language to be heard as expressing communication itself, independently of all symbolic and utilitarian functions of language, [...] translatability, as an objective category of the work of art, points beyond the original itself. Rather than aspiring to a fulfilment of the original, translatability indicates the work of art's search for a fulfillment in something other than

22 "Über Sprache uberhaupt und uber die Sprache des Menschen" (1915-1916); GS II, 1:140-157.

3 "...es ist jedem wesentlich, seinen geistigen Inhalt mitzuteilen." GS II, 1:141. 
the original itself. Translatability, as a call in the work of art, calls for a liberation of the work of art from itself. ${ }^{4}$

What I want to propose here is that translatability, as Benjamin understands it, can be considered a special case of the general property of language Derrida called "iterability." Iterability, the possibility of repetition, is that which, within any utterance, exceeds the utterance as such, escapes any given spatial, temporal, or intentional context, and points toward the possibility of saying (writing, reading) "the same thing" in an infinite variety of other contexts. For Derrida, iterability is a constitutive feature of language; all language is always in principle iterable, and a word that could not be repeated would simply not be a word. Benjamin's argument implies, however, that at any given point in a work's life, only certain parts or aspects of the work are translatable - precisely those which exceed, or can be torn free from, the function or mode of meaning that determines them in other contexts, and thereby adumbrate pure language, language as such, die reine Sprache or die Sprache überhaupt.

My purpose in introducing the category of iterability here is thus twofold : to clarify the place of translation in Benjamin's thought by situating it with respect to other modes of iteration he discusses, and more generally, to suggest a different way of thinking about translation.

Benjamin implies in "The Translator's Task" itself that translation is only one of the modes of the work's survival or

${ }^{4}$ Rodolphe Gasché, "Satumine Vision and the Question of Difference : Reflections on Walter Benjamin's Theory of Language." In Rainer Nägele, ed., Benjamin's Ground : New Readings of Walter Benjamin (Detroit : Wayne State U. P., 1988), p. 90.

5 "Signature Événement Contexte ", Marges de la philosophie (Paris : Minuit, 1972), p. 375. 
afterlife. The Romantics, he writes, had far more insight than others into the life of art works, but directed almost all their attention to criticism, "which also represents a phase, even if a lesser one, in the continuing life of the work..$^{16}$ Criticism is another mode of iteration, even if it operates negatively; it is another way of repeating, recontextualizing or reperforming the work of art and thereby reviving it and/or extending its life. Criticism cites the work, summons it before the bar of judgment, but also calls it as a witness, quotes it. And quotation is, of course, a special case of citation, one which involves repetition verbatim of another text. Thus we can identify at least three modes of iteration involved in the survival of the work : translation, criticism or critical commentary, and quotation. The relations between translation and criticism (and translation as criticism) have been explored at some length; I will focus here on the relations between translation and quotation, which seem to me to offer further prospects for translation studies.

Benjamin does not refer to quotation as such in "The Task of the Translator." The importance of quotation in Benjamin's writing is well-known however, and has been discussed by a number of critics. ${ }^{7}$ Benjamin claimed that his book on the origin of German tragic drama was based on no less than 600 quotations; the so-called Passagen-Werk is also largely a collection of quotations with commentary, a form he practiced in a less radically

6 "[...] die ebenfalls ein wenn auch geringeren Moment im Fortleben der Werke darstell" (GS 4, 1:15).

${ }^{7}$ Significant recent studies include Josef Furnkas, "Zitat und Zerstörung. Karl Kraus und Walter Benjamin," in Verabschiedung der (Post-) Moderne? : eine interdisziplinare Debatte, ed. Jacques Le Rider and Gérard Raulet (Tubingen : Narr, 1987), pp. 209-225; James L. Rolleston, "The Politics of Quotation : Walter Benjamin's Arcades Project," PMLA 104 (1989), pp. 13-27; Ian Balfour, "Reversal, Quotation (Benjamin's History)," MLN 106 (1991), pp. 622-647. 
experimental form in his book Deutsche Menschen. Moreover, Benjamin discusses quotation in several of his works, notably in his essay on the Viennese moralist Karl Kraus, which I propose to examine in some detail in order to bring out its bearing on translation.

The first thing to notice, perhaps, is that in the Kraus essay Benjamin makes much the same claim for quotation that he makes for translation in "The Task of the Translator." Like translation, quotation "transplants" a text into a new context, and in so doing both destroys and saves it. It "destroys" the text by wrenching it out of its former context, turning it away from its previous intention and meaning, and at the same time "saves" it by revealing in it an authentic truth that was obscured by its former context. In this way both translation and quotation ultimately reveal the nature of language as such : the iterability of the word manifests the origin of language beyond the determination of any context.

Kraus's great achievement, according to Benjamin, was to have made even newpapers quotable : by quoting the formulas and clichés ("Phrasen") of contemporary journalism in the context of his verse and essays, Kraus transfers them into another space, wrenching them free from the toils of inauthentic language that bound them in their original context and revealing - "saving"the true language hidden within them :

In the quotation that both saves and chastises, language proves the matrix of justice. It summons the word by its name, wrenches it destructively from its context, but precisely thereby calls it back to its origin. It appears, now with rhyme and reason, sonorously, congruously, in the structure of a new text. As rhyme it gathers the similar into its aura; as name it stands alone and expressionless. In quotation the two realms - of origin and destruction - justify themselves before language. And conversely, only where they interpenetrate - in quotation - is language consummated. In it is mirrored the angelic tongue in 
which all words, startled from the idyllic context of meaning, have become mottoes in the the book of Creation. ${ }^{8}$

In this passage Benjamin says explicitly that language is perfectly realized, consummated - vollendet - only in quotation, a claim he also makes for translation in "The Translator's Task." This can be taken as reflecting a penchant for hyperbole, or as indicating the intimate relation between quotation and translation; obviously, I lean toward the latter interpretation. The "origin" toward which quotation calls the word back is not its original meaning in the quoted text, but rather its essence or nature as pure language. ${ }^{9}$ The "angelic language" mirrored in quotation is thus the true language alluded to in "The Translator's Task," language set free from the all-too-human context of meaning - that is, set free from its use as a mere vehicle for the transmission of a meaning alien to itself - and redirected toward its origin in the divine word. Thus Benjamin notes that while Kraus began only late in his career to see that the problems of society and language that preoccupied him required a materialist and not an idealist solution, he first

8 "Karl Kraus," in Reflections, trans. Edmond Jephcott (New York : Harcourt Brace, 1978), p. 269; "Im rettenden und strafenden Zitat erweist die Sprache sich als Mater der Gerechtigkeit. Es ruft das Wort beim Namen auf, bricht es zerstorend aus dem Zusammenhang, eben damit aber ruft es dasselbe auch zurlick an seinen Ursprung. Nicht ungereimt erscheint es, klingend, stimmig, in dem Gefuge eines neuen Textes. Als Reim versammelt es in seiner Aura das Ähnliche; als Name steht es einsam und ausdruckslos. Vor der Sprache weisen sich beide Reiche Ursprung so wie Zerstorung - im Zitat aus. Und umgekehrt : nur wo sie sich durchdringen - im Zitat - ist sie vollendet. Es spiegelt sich in ihm die Engelsprache, in welcher alle Worte, aus dem idyllischen Zusammenhang des Sinnes aufgestört, zu Motti in dem Buch der Schöpfung geworden sind" (GS 2,1:363).

${ }^{9}$ Cf. Bemd Witte, Walter Benjamin, trans. James Rolleston (Detroit : Wayne State University Press, 1991), p. 77. 
"discovered in quotation the power, not to preserve, but to purify, to rip out of context, to destroy; the only power in which there remains any hope that something will outlast this era - precisely because it has been wrenched out of it."10 The language of any historical moment can be assured continuing life, and can be "translated" upward toward the realm of pure language, " only by violently ripping it out of the mythical web of determination that entraps it, and displaying it in a different context. For Benjamin, quotation and translation, along with the "allegorical" criticism he practices in his studies of Goethe's Elective_Affinities and German tragic drama, ${ }^{12}$ are the modes in which the deliverance of the word may be realized.

In Benjamin's account, Kraus's liberation of the word through his practice of quotation has two phases. In the first, the text quoted is removed from the realm of ordinary, natural language by being incorporated into a poem, by being subjected, for instance, to rhyme, and thus to a linguistic order independent of both syntax and meaning. Rhyme is, of course, an elementary mode of iteration, not of the word, but of its sound, and thus signals an inner relation between words based on an inherent similarity (das Ahnliche). The second moment involves naming; quotation names, as we shall see, not the meaning of the original text, but the original text itself.

When Benjamin identifies quotation as the fundamental procedure of Kraus's satirical critique, he in fact connects it with

10 [...] entdeckte im Zitat die Kraft : nicht zu bewahren, sondern zu reinigen, aus dem Zusammenhang zu reißen, zu zerstören; die einzige, in der noch Hoffnung liegt, daß einiges aus diesem Zeitraum uberdauert weil man es nämlich aus ihm herausschlug" (GS 2,1:365).

${ }^{11}$ Cf. Witte, p. 36.

${ }^{12}$ Cf. Witte, pp. 56-64, p. 82. 
naming : "From within the linguistic compass of the name, and only from within it, can we discern Kraus's basic polemical procedure : quotation. To quote a word is to call it by its name."13 This last sentence, which is repeated almost verbatim later in the same paragraph, is crucial, and requires explication.

Benjamin's essay "On Language as Such and on the Language of Man" had already identified naming as the fundamental human language act, which repeats Adam's naming of the animals in the Bible, and distinguished it from the symbolic and utilitarian functions of language. Benjamin categorically rejects what he calls the "bourgeois" conception of words as signs whose connection with their objects is purely conventional and whose meaning is determined by their relation to other signs in the same linguistic system (that is, the view we associate with Ferdinand de Saussure). For Benjamin, the word as name is immediately related to its object. Naming melds subject and object in a single cognitive act that recognizes the residue of the divine creative word in the object, and thereby reveals language as the sole medium of truth. What naming names is that within the object which is communicable-and therefore is already linguistic in nature. And naming is a mode of iteration as well, since it both echoes the mute language of objects and repeats on another level the act of naming inherent in the divine creative word.

By connecting naming with quotation in the Kraus essay, Benjamin makes it clearer just what calling a word by its name entails. In order to understand this in the present context it may be helpful to recall the distinction between "mention" and "use" current in the philosophy of language : we mention a word when

13 "Karl Kraus," p. 268 (I have corrected an error in Jephcott's translation here). Aus dem Sprachkreis des Namens, und nur aus ihm, erschließt sich das polemische Grundverfahren von Kraus : das Zitieren. Ein Wort zitieren heißt es beim Namen rufen" (GS 2,1, p. 362). 
we refer to it as such, rather than using it to refer to an object, event, idea, etc.; for example, when we say that the German word "Zitat" has five letters, or that it means "quotation" in English. Thus when we quote a word we call it by its name in the sense that we name the word itself, as such, uberhaupt; a quotation mentions or refers to the original word, which in turn refers to an object or meaning. For this reason, as Antoine Compagnon has pointed out, the criterion for judging a quotation is not truth (the correspondence of a proposition to its object) but authenticity (the correspondence of the quotation to the text quoted). ${ }^{44}$

The logical structure of quotation is, I would argue, also characteristic of translation as Benjamin understands it. Translation mentions rather than uses the original text, and this is reflected in the importance accorded the notion of fidelity in the history of translation theory : traditionally, one does not ask whether a quotation or a translation is "true," but rather whether it is an accurate or faithful iteration of the original text.

The relation between the logic of quotation and that of translation can be developed further if we adopt the distinctions introduced by Frege in his famous paper "On Sense and Reference" (Uber Sinn und Bedeutung), which was first published in 1892 and may well have been known to Benjamin. The Bedeutung or denotation of a sign, for Frege, is its referent, the object to which it refers; its Sinn or connotation is its specific mode of reference. Thus, to use Frege's example, the expressions "morning star" and "evening star" denote the same object (the planet Venus), and thus have the same Bedeutung, but they constitute two distinct modes of reference to that object; that is, they differ in their Sinn.

Frege's distinction corresponds, I believe, to that drawn by Benjamin in "The Translator's Task" between "the intended object"

${ }^{14}$ La seconde main ou le travail de la citation (Paris : Seuil, 1979), p. 87. 
(das Gemeinte) and "the mode of intention"' (die Art des Meinens), which he regards as necessary for understanding the law of the complementarity of languages..$^{15}$ To use Benjamin's example, the German word Brot and the French word pain have the same denotation but differing connotations. Employing Frege's terminology, Compagnon offers the following schematic analysis of the logic of citation (86) :

Original text

Quotation

(direct)

$$
\text { denotation of original }
$$

original text text

Connotation

connotation of
original text

connotation of quotation as act
Paraphrase

(indirect)

connotation of

original text

connotation

of paraphrase

as act

If we try to situate translation on this grid, it seems to fall somewhere between quotation and paraphrase (or critical commentary, to recall the iterative triad mentioned earlier), in that it claims to reproduce the original in the mode of direct discourse but in different words, so that one might paradoxically define translation as quotation in another language. ${ }^{16}$ And in fact, whereas traditional translation theory, by emphasizing the transmission of

is Cf. "On Language as Such and on the Language of Man" : "The distinction between the spiritual entity and the linguistic entity in which it communicates is preliminary to any investigation in linguistic theory"; "Die Unterscheidung zwischen dem geistigen Wesen und dem sprachlichen, in dem es mitteilt, ist die urspringlichste in einer sprachtheoretischen Untersuchung..." (GS, 2,1:141).

${ }^{16}$ More paradoxically, one might even say that in Benjamin's view translation is quotation in a different language, insofar as it denotes the word rather than the meaning of the original. 
sense ( $\operatorname{Sinn}$ ), treats translation as a form of paraphrase or indirect discourse, Benjamin links translation with quotation or direct discourse by emphasizing translation of the word as name, as denomination or denotation, rather than the word's Sinn or connotation. This can also help us understand, perhaps, Benjamin's defense of word-for-word translation (Wörtlichkeit). If translation, like quotation, denotes the text of the original, then what it translates is the words of the original, not their sense.

What, then, does translation itself connote? Like both quotation and paraphrase, I would suggest, translation connotes itself as an act; or in Benjamin's terms, what translation communicates is translatability.

The distinction between direct and indirect discourse is, however, problematic in both quotation and translation. In the case of Kraus's practice of quotation, Benjamin suggests, it is fundamentally undecidable. In Kraus's work, quotation involves a kind of mimicry of the object of satire that blurs the distinction between quoter and quoted, and at the same time institutes a critical distance between them. It was, of course, just this ambivalence that Plato denounced in dramatic mimesis, preferring a narrative diegesis that makes it clear just who is speaking. Thus it is no accident that Benjamin repeatedly stresses the dramatic aspect of Kraus's practice of quotation. The quotations in Die Fackel, he writes, provide more than evidence for Kraus's assertions; they provide the necessary stage-props (Requisiten) for his unmasking (Entlarvung) of his enemies (GS 2,1:347). Kraus's own dramatic mask, Benjamin suggests, is that of Shakespeare's Timon, the misanthropist who condemns the follies and vices of other men (GS 2,1:357). Yet like an actor, Kraus needs a stagepartner to provide him with the cues (Stichwörter) that are the indispensable basis of his critique. Kraus's dramatic practice of quotation thus reflects both his implication in his culture and his desire to free himself from it; his passion for imitating the language of his contemporaries, Benjamin suggests, expresses both 
his inevitable complicity in this inauthentic language and his battle against it (GS 2,1:348).

I turn now to Benjamin's own practice of quotation in "The Translator's Task." One of the reasons this essay is so difficult to understand is that Benjamin gives very few specific examples to illustrate or prove his points; the Brot and pain example mentioned earlier is virtually the only one. He mentions the work of Luther, Voss, Hölderlin, and George as examples of the kind of translation he is promoting, but quotes no passages from them that might clarify his view. One might find this peculiar, given the important role played by quotations in his other critical essays, and an unsympathetic reader might be tempted to attribute it to Benjamin's lack of interest in making his writing easily accessible, or even to his inability to connect his highly abstract argument with concrete textual examples.

There are, however, two lengthy quotations in "The Translator's Task," one from the French symbolist poet Stéphane Mallarmé, and the other from the German writer Rudolf Pannwitz. ${ }^{17}$ Both are cited, not as examples of the kind of

${ }^{17}$ Mallarmé : "Les langues imparfaites en cela que plusieurs, manque la suprême : penser étant écrire sans accessoires, ni chuchotement mais tacite encore l'immortelle parole, la diversité, sur terre, des idiomes empêche personne de proférer des mots qui, sinon, se trouveraient, par une frappe unique, elle-même matériellement la vérité" (GS 4,1:17). Pannwitz: "unsre tibertragungen auch die besten gehn von einem falschen grundsatz aus sie wollen das indische griechische englische verdeutschen anstatt das deutsche zu verindischen vergriechischen verenglischen. sie haben eine viel bedeutendere ehrfurcht vor den eigenen sprachgebräuchen als vor dem geiste des fremden werks ... der grundsătzliche intum des übertragenden ist dass er den zufälligen stand der eignen sprache festhalit anstatt sie durch die fremde sprache gewaltig bewegen zu lassen. er muss zumal wenn er aus einer sehr fernen sprache übertragt auf die letzten elemente der sprache selbst wo wort bild ton in eins geht zurück dringen 
translation Benjamin is promoting, but rather as authorities, as statements about language that articulate or support his view.

Mallarmé is cited in French, not in German translation; why? Perhaps because Benjamin assumes that the reader of his translation of Baudelaire (we should recall here that "The Translator's Task" was written as the introduction to Benjamin's translation of Baudelaire's Tableaux parisiens) can read French, a significant assumption to which I will return in my closing remarks. Perhaps also because, as we have seen, the decontextualization to be carried out by translation has already been realized in another mode by the process of quotation itself. And finally, perhaps, because Mallarmé's language has already removed itself from the realm of natural language, particularly through its disruption of normal syntax, ripping words out of the web of syntactical structure and displaying them as names whose primary relation is not to other words in the language but to things.

One can say much the same about the quotation from Pannwitz, which violates not only normal German syntax but also conventions concerning punctuation and capitalization. What is further remarkable here is that Pannwitz's point is one that had been made by Schleiermacher in his famous 1813 lecture on "Methods of Translation" which Benjamin never mentions, and also by Wilhelm von Humboldt. ${ }^{18}$ Why, then, did Benjamin choose

er muss seine sprache durch die fremde erweitern und vertiefern man hat keinen begriff in welchem masse das mogglich ist bis zu welchem grade jede sprache sich verwandeln kann sprache von sprache fast nur wie mundart von mundart sich unterscheidet dieses aber nicht wenn man si allzu leicht sondern gerade wenn man sie schwer genug nimmt" (GS $4,1: 20$ ).

${ }^{18}$ In unpublished notes on translation written around 1935, Benjamin mentions Humboldt's theory of language in this connection. See GS 6:158. 
to cite Pannwitz rather than these celebrated authors of the early nineteenth century, a period he knew well and on which he had written at length in the doctoral dissertation completed a few years earlier? One reason is perhaps that Pannwitz's German, like Mallarmé's French, subverts the linguistic structure of the language, and particularly its syntax-and might thus be seen as having already achieved the kind of liberation of the word that translation is supposed to provide. One might even say that the passages quoted from Mallarmé and Pannwitz are already translations from their respective languages, and thus not retranslatable, as Benjamin suggests in "The Translator's Task" (GS 4,1:15).

Though Benjamin never mentions Baudelaire in "The Translator's Task,"19 by making this essay the preface to his translations of Baudelaire's Tableato parisiens he transplants the latter into his own discourse, quotes them and makes them potential examples of his theory of translation. However, it is not at all clear how or whether Benjamin's translations of Baudelaire realize the kind of translation he describes in his preface. They may succeed in creating in German an "echo" - that is, an iteration - of the pure language struggling for recognition in the original French, as Benjamin urges; ${ }^{20}$ perhaps they can even be seen as

${ }^{19}$ It is clear, however, that "The Translator's Task" was written as a preface to the translations, and was composed long after the latter were largely completed. Benjamin had begun work on the translations as early as 1914, according to a letter he wrote to Hoffmansthal in 1923; the earliest extant manuscript draft dates from 1915 (GS 4, 2:890). Benjamin was thus working on the translations at about the same time as he was writing his essay "On Language as Such and on the Language of Men."

${ }^{20}$ GS 4,1:16. Cf. GS 6:159-60: "Jenes von Stresemann lacherlich gemeinte Wort : 'Man spricht Französich in allen Sprachen' ist ernster als er meinte, denn der Sinn der Ubersetzung ist tberhaupt: die fremde Sprache in der eignen zu repräsentieren." 
making contact with the original at only the most infinitesimal point of sense or meaning, as Benjamin suggests genuine translations do. But on first inspection, at least, it seems clear that Benjamin's translations are not "literal" in any ordinary sense, and certainly not "interlinear" in the mode of the interlinear translation of the Bible which Benjamin famously describes, in the last sentence of "The Translator's Task," as "the prototype or ideal of all translation" (GS 4,1:21).

Given the huge volume of critical commentary on Benjamin, and particularly on his theories of language and translation, it is surprising how little attention has been paid to the relation between "The Translator's Task" and the translations it introduces. ${ }^{21}$ Can the perspective adopted here - that is, the perspective in which translation is seen as a mode of iteration shed any light on this issue?

First, we need to clarify the concept of "literal translation," whose sense in English has always been somewhat muddied by the confusion of two notions that remain more easily distinct in German : Wörtlichkeit and Buchstäblichkeit..$^{22}$ A wörtliche translation is literal in the sense that it corresponds verbatim, wordfor-word, to the original; a buchstäbliche transiation is literal in the sense that it is not figurative or tropical. Though no doubt Benjamin also favors buchstäbliche translation (since a figurative translation would turn or trope on the meaning conveyed rather

${ }^{21}$ A notable exception is Andrew Shields, "Finding Poetry in Translation : Walter Benjamin's Translations of Baudelaire," Translation and the (Re)production of Culture (Selected Papers of the CERA Research Seminars in Translation Studies 1989-1991), ed. Clem Robyns (Leuven, 1994).

${ }^{22}$ Though confusion remains possible in German as well : "Sie sollten das nicht wörtlich nehmen..." means : You mustn't take that literally, i.e., at face value, but rather figuratively. 
than on the word itself), the expression he uses in "The Translator's Task" is, of course, Wortlichkeit, and its implications are made very clear in the following passage :

On the contrary, the meaning of the fidelity ensured by literal translation is that the great longing for the completion of language is expressed by the work. True translation is transparent, it does not obscure the original, does not stand in its light, but rather allows pure language, as if strengthened by its own medium, to shine even more fully on the original. This is made possible above all by conveying the syntax word-for-word, and this demonstrates that the word, not the sentence, is the original element of translation. For the sentence is the wall in front of the language of the original, and word-for-word rendering is the arcade..$^{23}$

Benjamin here praises literal translation - that is, wordfor-word translation - for precisely the reason it is damned by writers like Horace and Dryden : by the very fidelity of its iteration of the original's word order it disrupts the latter's syntax, and therefore its meaning. If, as we have seen, word-for-word transcription is required of quotation, it is traditionally rejected as a mode of translation because quotation is conceived as a repetition of words, and translation as a repetition of meaning.

Interlinear translation is in fact the ultimate paradigm of word-for-word translation, often producing a result that looks

23 "Vielmehr ist eben das die Bedeutung der Treue, welche durch Wörtlichkeit verbürgt wird, daß die große Sehnsucht nach Sprachergänzung aus dem Werke spreche. Die wahre Ubersetzung ist durchscheinend, sie verdeckt nicht das Original, steht ihm nicht im Licht, sondern laßt die reine Sprache, wie verstäkt durch ihr eigenes Medium, nur um so voller aufs Original fallen. Das vermag vor allem Wortlichkeit in der Übertragung der Syntax und gerade sie erweist das Wort, nicht den Satz, als das Urelement des Ubersetzers. Denn der Satz ist die Mauer vor der Sprache des Originals, Wortlichkeit die Arkade" (GS IV, 1:18). 
rather like the passages Benjamin quotes from Mallarmé and Pannwitz. By dislocating the seamless syntactical structures of the original - above all, the sentence, which Benjamin compares to a solid wall standing before the original and preventing the light of pure language from falling on it - literal translation tears words free from the bonds of syntax, logic, meaning, and radically decontextualizes them in a procedure analogous to that of quotation as Benjamin describes it in his essay on Karl Kraus.

As I noted earlier, however, Benjamin's translations of Baudelaire seem not at all wörtlich in this sense. Not only do his translations not follow the original word-for-word, but their German syntax is relatively normal; certainly it is less unconventional than that of the passages Benjamin quotes from Mallarmé and Pannwitz in his essay, even though these are presented as prose.

Benjamin himself seems to have seen no contradiction between the theory of translation set forth in "The Translator's Task" and the translations of Baudelaire it prefaces. On the contrary, in the advertising blurb he submitted to his publisher, $\mathbf{R}$. Weissbach, he wrote :

What will guarantee this translation its place is that on the one hand it conscientiously fulfills the requirement of fidelity, which the translator in his preface irrefutably establishes, and on the other it also convincingly catches the poetic element. ${ }^{24}$

24 "Was dieser Übertragung ihren Platz sichern wird, ist, daß in ihr einerseits das Gebot der Treue, welches der Übersetzer in seiner Vorrede unwiderleglich begrindet, gewissenhaft erfullt, andrerseits aber das Poetische überzeugend erfaßt wird (GS 4,2:893). Daß uberdies der Urtext, und zwar der erste philologisch-korrekte in Deutschland, des großen Lyrikers willkommen sein" (GS 4,2:893). 
The fidelity (Treue) he refers to here is defined in "The Translator's Task" as fidelity not to the meaning of the original (that is, to the meaning as something extrinsic conveyed by or through language), as in the traditional theory of translation, but rather as fidelity to the word of the original. As we have already seen in the passage quoted above, "The Translator's Task" explicitly links this fidelity, whose demands Benjamin claims to have "conscientiously" fulfilled in his translation of Baudelaire, with Wörtlichkeit, and even with interlinear translation. In what sense can this be the case?

The translator's task, Benjamin writes, consists in finding the "intention toward language" in the language into which he is translating the work that will awaken within it an echo of the original (GS 4,1:16). His translations of Baudelaire, as well as his comments on Kraus's practice of quotation, suggest that rhyme may be part of this intention, and it is obvious that rhymed verse translation of the kind Benjamin attempts is virtually incompatible with a primary emphasis on Wörtlichkeit understood as word-forword translation. Moreover, in comments in letters to his friends, Benjamin's chief criticism of his Baudelaire translations bears on their "metrical naiveté" (GS 4,2:893). In fact, the dislocation of syntax produced by word-for-word translation is also produced by the constraints of rhyme and meter, which free the poetic word from instrumentality and raise it toward pure language. Thus it seems clear that for Benjamin Wörtlichkeit entails more than the composition of a mere "trot," an interlinear translation of the kind students make in their copies of Virgil by writing the "literal," dictionary "equivalent" in their own language over each word in the Latin text.

But what, then, shall we say about the privilege accorded to interlinear translation? While Benjamin's translations of Baudelaire were not published in interlinear form, they nevertheless did appear along with the original French text of each poem, which was printed on the left-hand page, facing Benjamin's 
translations on the right-hand page. (Whether this might be taken to imply that in this case the "poetic word" (Dichterwort) is equivalent to the verse line, or even to the whole sonnet, I will not attempt to decide here.) This double presentation of original and translation was important to Benjamin. In the advertising blurb mentioned earlier, after stressing the fidelity of his translation, he adds : "In addition, the great lyric poet's original text, and in fact the first philologically accurate one published in Germany, will be weicomed. ${ }^{25}$ In other letters to Weissbach, Benjamin argues for minimal use of punctuation in his translations, on the ground that "this will best fulfill the requirement of a confrontation with the original." 26

Benjamin's iteration of Baudelaire's text is thus necessarily and not contingently twofold : it consists of a "philologically correct" reproduction (in accord with the norms of quotation) of the original French text, accompanied by a "faithful" translation into German. ${ }^{27}$ This double presentation is intended to

25 "Daß uberdies der Urtext, und zwar der erste philologisch-korrekte in Deutschland, des großen Lyrikers willkommen sein" (GS 4,2:893). In the publication information given in the volume, we read: "The French text of this separate edition of the "Tableaux parisiens" is literally faithful to the definitive edition"; "Dem französischen Text dieser Einzelausgabe der Tableaux Parisiens liegt buchstäbengetreu zu Grunde die Ausgabe letzer Hand" (GS 4,2:893; my emphasis).

26 "...dies die Confrontierung mit dem Original am besten gerecht wird" (GS 4,2:892).

${ }^{27}$ Cf. the unpublished fragment mentioned earlier, where Benjamin stresses the importance of bilingual texts in manifesting the difference of languages : "This happy mode of translation, which explains itself in commentary and also thematizes the fact of differing linguistic situations, has unfortunately in modern times increasingly disappeared. It flourished from the medieval translations of Aristotle to the seventeenth-century 
make possible a more legitimate confrontation of translation and original ("more legitimate," presumably, because based on a more accurate French text and a more faithful translation). This notion of a confrontation of the translation with the original seems to me to be of crucial importance in understanding the significance Benjamin attaches to interlinear translation and the relation between "The Translator's Task" and his own versions of Baudelaire.

As modes of iteration, both translation and quotation involve a reference to an original text, and to be recognized and evaluated as such, that is, qua translation and quotation, they must in some sense be read alongside the original. ${ }^{28}$ This can be promoted by interlinear translation, or by printing original and translation on facing pages, as in the case of Benjamin's Baudelaire; what matters is that the difference made by translation is made perceptible, just as the difference made by quotation is

bilingual, annotated editions of the classics. And precisely because a difference in the linguistic situation had developed, a translation could become an effective part of its own world. However, the application of this technique to poetic texts seems to me extremely problematic"; "Diese glückliche Form der Ubersetzung, die im Kommentar Rechenschaft von sich ablegt und das Faktum der verschiedenen Sprachsituation mit zum Thema macht, ist der Neuzeit leider in wachsendem Maß verloren gegangen. Sie hatte ihre Blüte in einer Epoche, die von den Aristotlesübersetzungen des Mittelalters bis zi den zweisprachigen kommentierten Klassikerausgaben des siebzehnten Jahrhunderts reicht. Und gerade weil die Verschiedenheit der Sprachsituation zugestanden war, konnte die Übersetzung wirksam, zum Bestandteil der eignen Welt werden. Aber allerdings scheint mir die Anwendung dieser Technik auf poetische Texte überaus problematisch" (GS 6:159).

28 This often takes the form of "hearing" the original behind the translation. In this regard, translation and quotation might be seen as modes of what Bakhtin calls "double-voiced discourse." 
made perceptible in Kraus's work. ${ }^{29}$ But of course difference is not made "perceptible" in the sense that it is presented to the senses; it operates, as Benjamin's metaphor suggests, "between the lines," in their differential relation to each other. For the movement away from language's embroilment in instrumentality and myth is adumbrated, not in the similarity of the two texts, but in their difference. Iterability, translatability, quotatibility are that part of the structure of a thing that differs from the thing itself, points toward something beyond it. For Benjamin, that beyond is pure language.

By way of an ending I return now to the rhetorical question Benjamin asks at the beginning of "The Translator's Task" : "Is a translation meant for readers who do not understand the original $?^{n 30}$ In the immediate context of Benjamin's argument, this question must surely be answered in the negative; translation, Benjamin maintains, should be understood not in relation to readers, not in relation to the human and natural, but in relation to something superhuman and supernatural, which he goes on to identify as pure language. But if - in accord with Benjamin's own theory and practice - we rip this question out of its immediate context and juxtapose it with the final paragraph of his essay, we might answer : translation in this sense is not intended for readers who do not understand the original, nor perhaps for any reader; but it calls for a reader who does understand the original.

\section{University of Oregon}

${ }^{29}$ On the difference transiation makes, see Gasché, "Saturnine Vision." For an amusing and provocative illustration of the difference made by any repetition of words, see Jorge Luis Borges, "Pierre Ménard, Autor del Quijote," Obras Completas (Buenos Aires : Emece, 1954), 2:45-57.

${ }^{30}$ "Gilt eine Übersetzung den Lesern, die das Original nicht verstehen?" (GS 4,1:9). 
ABSTRACT : Translation, Quotation, Iterability (Walter Benjamin) - Translatability can be considered a special case of the general property of language Derrida called "iterability." By focusing on this property I seek both to clarify the place of translation in Benjamin's thought with respect to other modes of iteration, such as critical commentary and quotation, and to suggest a different way of thinking about translation.

Like quotation, translation does not "use" the original text, but rather "mentions" or "names" it. Thus we can understand Benjamin's defense of word-for-word translation (Wörtlichkeit); if translation, like quotation, denotes the text of the original, then what it translates is not the sense of the original, but its word. Similarly, what translation connotes is translation itself considered as a possible act, or to put the point in Benjamin's and Rodolphe Gasche's terms, it communicates translatability.

Iterability, translatability, and quotability are that part of the structure of a linguistic entity that differs from the entity itself, and points toward something beyond it. For Benjamin, that beyond is pure language.

RÉSUMÉ : Traduction, citation, itérabilité - Dans la " traductibilité " on peut voir un cas particulier de la propriété linguistique générale à laquelle Derrida a donné le nom d' " itérabilité ». En me penchant sur l'itérabilité je cherche à mieux définir la place de la traduction dans la pensée de Benjamin et en même temps à suggérer une nouvelle perspective sur la traduction elle-même.

Comme la citation, la traduction n'emploie pas le texte original, mais plutôt le mentionne ou le nomme. Ainsi on peut comprendre la défense benjaminienne de la traduction mot-à-mot (Wörtlichkeit); si comme la citation la traduction dénote le texte de l'original, elle traduit non pas le sens mais le mot de l'original. De même, la traduction connote la traduction elle-même en tant qu'acte possible, ou pour le dire comme Benjamin et Rodolphe Gasché, elle communique la traductibilité. 
L'itérabilité, la traductibilité, la citabilité constituent cette part de la structure d'une entité linguistique qui diffère de l'entité en soi et se réfêre à quelque chose au-delà. Pour Benjamin, cet au-delà, c'est le langage pur.

Steven Rendall : Quartier de l'Église, 82100 Les Barthes, France. 